\title{
Risks and Countermeasures of Local Government Debt in China
}

\author{
Siyuan Dai \\ College of Economics, Jinan University, Guangzhou, China \\ Email: 15191484227@163.com
}

How to cite this paper: Dai, S. Y. (2020). Risks and Countermeasures of Local Government Debt in China. Modern Economy, 11, 1611-1620. https://doi.org/10.4236/me.2020.1110112

Received: September 8, 2020

Accepted: October 26, 2020

Published: October 29, 2020

Copyright $\odot 2020$ by author(s) and Scientific Research Publishing Inc. This work is licensed under the Creative Commons Attribution International License (CC BY 4.0).

http://creativecommons.org/licenses/by/4.0/

\begin{abstract}
In recent years, local governments have adopted the method of debt financing, which has promoted the development of economy and society and accords with the requirements of macro policies. However, with more and more demand of livelihood security and infrastructure, this has aggravated its financial pressure for the limited regional finance. The local government has increased its borrowing scale to meet public demand. The problems of local government debt like huge size, imperfect management, opaque information, inefficient supervision, and incomplete laws increase the risk of local government debt. This paper did a detailed research on the current situation of the local government debt that exceeds a certain limit financial risk, credit risk and efficiency risk.
\end{abstract}

\section{Keywords}

Local Government Debt, Debt Risk, Debt-Resolving

\section{Introduction}

With the gradual advance of China's opening-up policy, its domestic economy has achieved rapid development, while the scale of local government debt has also maintained rapid growth. From 1997 to 2014, China's local government debt grew at a particularly rapid rate, with an average annual growth rate of 29.4 percent. However, China's local government debt lacks the support of relevant laws and normative management mechanism, which has not formed an effective supervision mechanism for local government debt.

In 2011 and 2013, China's National Audit Office conducted audits of local governments' debts nationwide. Before the audit, local governments were reluctant to disclose and report their debts voluntarily, so the published statistics were not comprehensive and accurate. In 2015 and 2016, the state introduced relevant measures to prevent and defuse risks, and the new Budget Law was introduced 
in 2017. In 2018, the Ministry of Finance launched a series of policies, such as the Notice on Managing Local Government Debt well. All these measures show that China has begun to take measures to address the local debt problem.

From the perspective of future development, the promotion of China's urbanization strategy is bound to have a huge demand for funds, and many local governments whose debts are not optimistic are bound to be short of funds of this process. Therefore, it is necessary to take the local government debt risk of China as the research object, analyze its internal causes and explore solutions to alleviate the local government debt pressure.

\section{Literature Review}

\subsection{Research on the Causes of Local Government Debt Risks}

Wang Jun (2015) proposed that the main causes of China's local debt problems are as follows: financial system, policy factors and so on. In other words, in the face of the active regulation and control policies implemented by the central government, the local government may expand its borrowing scale. In addition, the implementation of some national policies, such as urbanization construction, will also lead to the expansion of debt. Jiang Di (2016) believes that the local government debt risks of China are mainly caused by the unreasonable allocation of financial and administrative powers between local governments and the central government, the fact that local governments had not established a scientific and reasonable performance appraisal mechanism for officials, and the lack of transparency and science in local debt management. Gong Junliang (2016) pointed out that due to the lack of financial budget supervision and the underdeveloped capital market, Chinese local governments have accumulated a lot of direct and contingent debts through local financing platforms. However, Tian Li (2017) pointed out that the most fundamental reason why local governments continue to increase their scale of borrowing is their own limited financial funds and the expansion of government administrative functions.

Daniel Becker and Michael Rauscher (2013) analyzed the local debt data of more than 30 countries, analyzed the debt scale of these countries, and analyzed the influencing factors of the debt scale, including investment intensity, policies and regulations, etc. Frankel (2011) proposed that future economic expectations would have an impact on government borrowing behavior. If local governments believe that the future economic development trends are great and hold a positive and optimistic attitude, then local governments will increase their borrowing scale. Wu \& Feng (2014) studied the reasons for the formation of information asymmetry in municipal bond market and the problems caused by such information asymmetry.

\subsection{Research on Prevention of Local Government Debt Risks}

Wang \& Yu (2015) proposed that in order to prevent the debt risks of Local governments in China, it is necessary to actively promote the reform of the gov- 
ernment accounting system under the cash basis system, continuously improve the fiscal budget system, strengthen the management of debt budget, and unify the statistical calibre of the debt scale. Zhu Lei (2015) proposed that in debt risk management of Local governments in China, risks should be prevented according to three stages, namely, before, during and after the event. Xu Pengcheng (2016) believes that in order to prevent debt risks, local governments can introduce a reserve fund system, in which the government's debt funds are stored in a special financial account in a certain proportion. Once debt risks occur, the funds can be used to repay debts and interest, so as to reduce the possibility of default risks. Zhang Weiwei (2018) pointed out that in order to fundamentally solve the hidden risks of local debt, it is necessary to accelerate the reform of government accounting system, so as to realize the reasonable division of financial power and administrative power between the central and local governments, improve the degree of tax distribution, and completely reduce the dependence on local governments on debt funds.

\section{The Present Situation of Local Government Debt in China}

\subsection{The Scale of Debts}

According to the data of " 2018 Local Government Bond issuance and debt balance" released by the Ministry of Finance of China, by the end of 2018, the outstanding debt of China's local governments stood at 16.47 trillion yuan, with a debt ratio (outstanding debt/comprehensive financial resources) of 76.5 percent, which is lower than 100 percent of the common international warning standard. In addition, taking into account the central government's outstanding debt of 13.48 trillion yuan, China's total government balance is nearly 30 trillion yuan. In 2018, China's GDP was calculated at 82.71 trillion yuan. It can be calculated that the government debt ratio reached $36.2 \%$ in $2018,0.5$ percentage point lower than that in 2016 and far less than $60 \%$ of the "warning line" stipulated in the Maastricht Treaty. The risks are generally under control.

By December 2019, the National Audit Office of China had conducted two comprehensive audits of local government debt in 2010 and 2013 respectively. In view of the availability of data, the composition of local government debt, the source of debt funds and the direction of debt were analyzed based on 2013 audited data.

\subsection{The Composition of Debts}

By the end of the second quarter of 2013, in total provincial debt, the proportion of government paid debt, guaranteed debt repayment and debt that may bear the liability for relief was around $30 \%$ respectively, and the distribution was relatively uniform (see Table 1 below).

\subsection{The Sources of Funding for Debts}

By the end of June 2013, according to the audit results, bank loans totaled 
Table 1. Composition of China's Local government debt at the end of June 2013 (unit: 100 million YUAN).

\begin{tabular}{|c|c|c|c|c|c|c|c|c|}
\hline & \multicolumn{2}{|c|}{ At the provincial level } & \multicolumn{2}{|c|}{ The municipal } & \multicolumn{2}{|c|}{ At the county level } & \multicolumn{2}{|c|}{ The villages and towns } \\
\hline & debt & Accounted for & debt & Accounted for & debt & Accounted for & debt & Accounted for \\
\hline Debts to be repaid & $17,780.9$ & $34.2 \%$ & $48,434.6$ & $66.4 \%$ & $39,573.6$ & $78.5 \%$ & 3070.1 & $84.2 \%$ \\
\hline Debts to be guaranteed & $15,627.6$ & $30.1 \%$ & 7424.1 & $10.2 \%$ & 3488.0 & $6.9 \%$ & 116.0 & $3.2 \%$ \\
\hline $\begin{array}{l}\text { Debts that may bear the } \\
\text { liability for relief }\end{array}$ & $18,531.3$ & $35.7 \%$ & $17,043.7$ & $23.4 \%$ & 7357.5 & $14.6 \%$ & 461.2 & $12.6 \%$ \\
\hline A combined & $51,939.8$ & $100 \%$ & $72,902.4$ & $100 \%$ & $50,419.2$ & $100 \%$ & 3647.3 & $100 \%$ \\
\hline
\end{tabular}

Source: announcement No. 32 of the national audit office of China in 2013: audit results of national government Debt (2013.12.30).

1.011874 trillion yuan, accounting for $56.6 \%$ of China's total local government debt. In addition, bond issuance is an important source of funds of local governments, second only to bank loans, totaling 1845.69 billion yuan, accounting for 10.3 percent of the total debt (see Table 2 below).

\subsection{The Whereabouts of the Funds of Debts}

By the end of June 2013, it can be seen from the following table that the debt funds of local governments mainly flow to three aspects: municipal construction, construction of transportation facilities and land purchase and storage. The total amount of three types of debt invested by local governments in these three areas is 11.77501 trillion yuan, accounting for $70.3 \%$ of the total local debt expenditure. It can be seen that most of the debt funds are used in the economic function areas of the government. The total amount of the three debt funds invested in many areas of government social functions, such as science, education, culture and health, ecological construction and environmental protection, is only 3.06477 trillion yuan, accounting for only $18.3 \%$ of the total debt. It is far lower than the investment of local governments in the field of economic functions. From the perspective of local government debt expenditure, in the impact on the scale of debt, the economic function of the government is far greater than its social function, and even plays a decisive role (see Table 3 below).

\section{Performance of Local Government Debt Risks in China}

\subsection{The Financial Risk}

The financial risks of local government debt mainly refer to the risks of local commercial Banks of their financial transactions with local governments, which are likely to pose a threat to the survival of the bank, generate a run risk, and thus threaten the sound operation of the entire financial system.

According to the 2013 audit of local government debt by the National Audit Office of China, bank credit accounts for 56.6\% of the total local government debt. By the end of 2018, the provision coverage ratio and loan provision ratio of China's commercial Banks had reached 181.42 percent and 3.16 percent 
Table 2. Financing sources of local government debt in China as at the end of June 2013 (unit: 100 million yuan).

\begin{tabular}{|c|c|c|c|c|c|}
\hline & \multirow{2}{*}{$\begin{array}{l}\text { Debts to be } \\
\text { repaid }\end{array}$} & \multirow{2}{*}{$\begin{array}{l}\text { Debts to be } \\
\text { guaranteed }\end{array}$} & \multirow{2}{*}{$\begin{array}{l}\text { Debts that may bear the } \\
\text { liability for relief }\end{array}$} & \multicolumn{2}{|c|}{ A combined } \\
\hline & & & & debt & Accounted for \\
\hline A bank loan & $55,252.5$ & $19,085.2$ & $26,849.8$ & $101,187.4$ & $56.6 \%$ \\
\hline BT (Build-Transfer) & $12,146.3$ & 465.1 & 2152.2 & $14,763.5$ & $8.3 \%$ \\
\hline Issuance of bonds & $11,658.7$ & 1673.6 & 5124.7 & $18,456.9$ & $10.3 \%$ \\
\hline Outstanding payment payable & 7781.8 & 90.99 & 701.8 & 8574.7 & $4.7 \%$ \\
\hline Trust financing & 7620.2 & 2527.4 & 4104.8 & $14,252.2$ & $8 \%$ \\
\hline $\begin{array}{l}\text { Other units and } \\
\text { Personal loan }\end{array}$ & 6679.2 & 551.8 & 1159.6 & 8392 & $4.8 \%$ \\
\hline $\begin{array}{l}\text { Underwritten construction } \\
\text { and deferred payment }\end{array}$ & 3269.2 & 12.7 & 476.7 & 3758.6 & $2.1 \%$ \\
\hline $\begin{array}{l}\text { Securities, insurance and other } \\
\text { financial institutions financing }\end{array}$ & 2000.2 & 309.7 & 1056.9 & 3365.4 & $2.1 \%$ \\
\hline $\begin{array}{l}\text { National debt, foreign debt and } \\
\text { other financial lending }\end{array}$ & 1325.2 & 1708.5 & 0.0 & 3031.7 & $1.5 \%$ \\
\hline Financing lease & 750.2 & 194.1 & 1374.6 & 2318.9 & $1.3 \%$ \\
\hline To raise money & 373.2 & 37.7 & 393.9 & 804.8 & $0.5 \%$ \\
\hline A combined & $108,859.2$ & $26,655.8$ & $43,393.7$ & $178,908.7$ & $100 \%$ \\
\hline
\end{tabular}

Source: announcement No. 32 of the national audit office of China in 2013: Audit results of national government debt (2013.12.30).

Table 3. The whereabouts of local government debt funds in China as of the end of June 2013 (unit: 100 million yuan).

\begin{tabular}{|c|c|c|c|c|c|}
\hline & \multirow{2}{*}{$\begin{array}{l}\text { Debts to be } \\
\text { repaid }\end{array}$} & \multirow{2}{*}{$\begin{array}{l}\text { Debts to be } \\
\text { guaranteed }\end{array}$} & \multirow{2}{*}{$\begin{array}{l}\text { Debts that may } \\
\text { bear the liability } \\
\text { for relief }\end{array}$} & \multicolumn{2}{|c|}{ A combined } \\
\hline & & & & debt & The percentage \\
\hline Municipal construction & $37,935.1$ & 5265.3 & $14,830.3$ & $58,030.6$ & $34.6 \%$ \\
\hline Land purchase and storage & $16,892.7$ & 1078.1 & 821.3 & $18,792.1$ & $11.2 \%$ \\
\hline Construction of transportation facilities & $13,943.1$ & 13,189 & $13,795.3$ & $40,927.4$ & $24.4 \%$ \\
\hline Affordable housing & 6851.7 & 1420.4 & 2675.7 & $10,947.8$ & $6.5 \%$ \\
\hline The science-education-culture-health & 4878.8 & 752.6 & 4094.3 & 9725.6 & $5.8 \%$ \\
\hline Agriculture, forestry and water conservancy construction & 4086 & 580.2 & 768.3 & 5434.3 & $3.2 \%$ \\
\hline Ecological construction and environmental protection & 3218.9 & 434.6 & 886.4 & 4539.9 & $2.7 \%$ \\
\hline Industry and energy & 1227.1 & 805.0 & 260.5 & 2292.6 & $1.4 \%$ \\
\hline Other & $12,155.6$ & 2110.3 & 2552.3 & $16,818.1$ & $10 \%$ \\
\hline A combined & $101,188.8$ & $25,635.4$ & $40,684.3$ & $167,508.5$ & $100 \%$ \\
\hline
\end{tabular}

Source: Announcement No. 32 of the national audit office of China in 2013: Audit results of national government debt (2013.12.30).

respectively, still relatively at a reasonable level (see Table 4 below).

Take Anhui Province as an example. According to the data of the 2018 financial budget and final accounts report of each municipal government, 11 of the 16 prefecture-level cities in the province have a debt ratio that exceeds $100 \%$ of the risk alert value determined by the Ministry of Finance, among which the highest 
Table 4. The provision coverage ratio and loan provision ratio of China's commercial Banks from 2016 to 2018.

\begin{tabular}{rccc}
\hline & In 2016 & In 2017 & In 2018 \\
\hline Provision coverage & $175.52 \%$ & $176.4 \%$ & $181.42 \%$ \\
Loan provision ratio & $3.09 \%$ & $3.08 \%$ & $3.16 \%$ \\
\hline
\end{tabular}

Data source: CBRC majored regulatory indicators in the fourth quarter of 2017 and 2018.

debt ratio is $271.75 \%$ and the lowest is $107.54 \%$.

According to incomplete statistics, by the end of 2018, China's local governments had lent more than 9 trillion yuan to the banking sector through local financing vehicles, accounting for 13.8 percentage points of the outstanding loans in the banking sector, and local commercial Banks will become their main source of financing. If the problem of financing vehicles' debt repayment appears on a large scale, it will not only undermine the stable operation of the financial market, but also reduce the loan volume of Banks due to the large number of non-performing loans, thus weakening the role of the central bank's expansionary monetary policy.

\subsection{The Credit Risk}

China's total expenditure of local public finance in 2013 was 11.1974 .034 billion yuan, of which regular expenditure on general public services, national defense, social security, employment and other items accounted for about 56 percent. In the same year, local public finance revenue totaled 11.70308 billion yuan. In the context of declining local land fiscal revenue and stricter management, local governments may have to use part of the public fiscal revenue to repay the huge local debts that will mature or sell government assets, which is bound to reduce part of the current expenditure and affect the normal investment expenditure. Eventually there may be passive liabilities such as arrears in civil servants' wages or gaps in social security funds, and arrears in project payments by local governments.

For example, in early January 2015, China Pacific Construction Group filed a lawsuit against six municipal and county-level people's governments across the country for arrears of payments. Local governments may thus face a degree of credit crunched.

\subsection{The Efficiency Risk}

From the perspective of recognition efficiency, China's current accounting system is not sufficient to reflect the real situation of local government debt in a timely manner. The cash basis system focuses on reflecting the cash inflow and outflow. If the government debt has not been paid in cash, it will not be disclosed. For example, the construction project payment due to enterprises becomes invisible debt. In addition, when the time of economic transactions and the actual time of cash receipts and payments are not the same accounting period, the cash basis of accounting conditions can not reflect the real situation of 
the current business.

\section{Analysis of the Causes of Local Government Debt Risks in China}

\subsection{The Proportion of Bank Credit in Local Government Financing Is Too High}

\subsubsection{Local Governments Need to Expand Financing}

In order to further to accelerate the pace of infrastructure construction and improve the service quality of public goods, local governments need to obtain more financial support from local government financing platforms and other channels. Due to the low profitability of local government investment projects and the lack of government cash flow, local governments are unable to achieve large-scale financing through the financial market and have to rely on local commercial Banks to obtain financing funds. As for these local commercial Banks, they are more or less subject to the intervention in local government officials in the decision-making of loan methods. However, commercial Banks need to develop business and carry out various business activities in their daily operation, and they need strong support and support from local governments. Therefore, Banks will choose to actively cooperate with government departments, so as to achieve the goal of obtaining favorable resources and developing their own business. In this case, the bank's lending to the financing platform also becomes non-compliant.

\subsubsection{Commercial Banks Prefer Government Projects}

On the one hand, the interest rate spread between deposits and loans is the main source of profits for Banks. Due to the relatively loose monetary policy currently implemented in China, the interest rate spread between Banks is getting smaller and the competition is more and more fierce, so Banks need to increase more loans in order to obtain more profits. However, the loan projects applied for by local government financing platforms are usually large in amount and take a long time. As long as the loan interest can be recovered in time, the risk will be less. Moreover, the increase in the loan amount in the short term can bring great benefits of the Banks. On the other hand, financing platforms will get promises from local governments in advance, such as loan guarantees and financial backends. Therefore, commercial Banks are more inclined to provide loans for them. However, they lack sufficient understanding and assessment of possible loan risks, leading to large amount of loans and high risks. Once local governments fail to ensure that they can repay the loans of financing vehicles, commercial Banks, as the main lenders, will be the first to be hit, further affecting the sound operation of the entire financial market.

\subsection{Inefficient Use of Debt Funds}

Local governments have long had problems with their investment strategies: first, they set too broad an investment horizon; second, the internal structure of 
public investment is unreasonable; The third is underinvestment in the emerging public sector. When the development of market economy becomes increasingly prosperous, the proportion of local governments' investment in competitive fields and profit-making fields is increasingly high. Such behavior will seriously discourage private investment in these fields, thus hindering the vigorous development of market economy and possibly inhibiting the further growth of market forces. In addition, local governments in China choose investment projects at will and fail to evaluate the future benefits of the projects. Inadequate supervision in the process of project construction leads to a large number of invalid projects, which are not only costly but also of low benefit.

\subsection{The Lag of the Reform of Government Accounting System}

In 2015, the Ministry of Finance issued the Basic Standard of Government Accounting standards, which was formally implemented in January 2017, which kicked off the reform of Chinese government accounting system. Compared with western countries, China's local government accounting system reformed started late, while accrual accounting system is complicated in operation, high in accounting technology, difficult to understand, and requires high professional knowledge level of accounting personnel, which further to slow down the pace of reform.

\section{Countermeasures to Prevent the Risk of Local Government Debt}

\subsection{Reduce Non-Performing Loans in Commercial Banks}

Bank loans to the financing platform, on the one hand, to the platform company and investigate the condition of the investment project, on the other hand, you want to communicate actively with the local government department, through the local government debt, debt structure and debt maturity that information, to assess the debt repayment ability of the government, to evade risk caused by information asymmetry. In addition, increasing the diversity of guarantee methods can also reduce the risk of loans to a certain extent. At the same time, the phenomenon of mutual guarantee between platforms should be avoided.

Secondly, implement hierarchical management of debt risk to improve the efficiency of credit resource allocation. There are differences in experience and seniority among different financing platforms. Banks can predict the interval of default risk of their future debts through prior investigation before issuing loans. For financing platforms with high default risk and debt ratio, Banks can refuse to extend loans to them. Different measures taken by Banks according to different levels of debt risk can effectively lower the probability of debt repayment risk and reduce the possible losses of Banks.

\subsection{Increase the Efficiency in the Use of Debt Funds}

6.2.1. The Investment Boundary of Local Government Is Strictly Defined For local governments, the public nature of investment should be strengthened 
and more debt funds should be used for those fields and projects that cannot be effectively allocated by market mechanism, such as the supply of public goods and services or some livelihood guarantee projects. And for those competitive fields, should reduce its investment proportion appropriately.

\subsubsection{Reasonable Adjustment of the Investment Structure of Local Governments}

At present, China's local governments have some irrational investment structure, such as too much investment in infrastructure and too little investment in technological transformation. The investment structure of local governments can be adjusted from two aspects: one is to adapt to the new public needs. The shortcomings in social infrastructure investment need to be fixed by local governments, especially in education, culture, medical treatment, pension and other related infrastructure construction. Second, it ADAPTS to the development of local enterprises. Local governments should give play to their resource advantages, make up for market failures, encourage technology spillover and diffusion, and focus their investment in the innovation of enterprise ecological environment and the improvement on basic research facilities.

\subsection{Promoting the Transition from Cash Basis to Accrual Basis}

\subsubsection{The Gradual Promotion of Accrual Basis}

The reform of the government accounting system should be carried out step by step rather than in a hurry. First of all, the current complete cash basis should be changed. After a period of transition and adjustment, the complete accrual basis should be finally realized. Accrual basis is first introduced into some accounting items, the rest of the items still use cash basis. After a certain foundation is laid for revising the accrual basis, the accrual basis is gradually adopted for other accounting items in financial statements to promote the final realization of revising the accrual basis.

\subsubsection{Improvement of Relevant Supporting Measures}

In order to realize accrual basis successfully, the government needs to introduce relevant regulations and policies and promote the realization of this goal through perfect supporting measures. For example, for the initial stage of the reform, it is necessary to strengthen publicity, improve the awareness of relevant personnel, and promote the recognition of the advantages of accrual basis. Reform participants should be trained to ensure that they have professional financial knowledge and operational proficiency. In addition, the accounting information system should be adjusted accordingly to adapt to the new accounting recognition, so that the national information system can be unified.

\section{Conclusion}

With the development of economy, the debt risks of Local governments in China will be increasingly abundant in both content and form, and it will be increasingly difficult to prevent debt risks. Therefore, it is necessary to study the risk of 
local government debt and its prevention countermeasures. By analyzing the current situation and causes of local government debt and its risks in China, relevant solutions are proposed. It is worth noting that the development of China's provinces is uneven, so the prevention and solution of local government debt should be flexible according to the situation of different provinces. Due to the lack of relevant official data on government debt in China, the statistical caliber still does not form a unified and authoritative standard. The data in this article is mainly derived from the 2013 audit report of the National Audit Office. Most of them are macroscopic and lack of various provinces, cities, and counties, the more comprehensive and specific data, so there are certain limitations in the study of debt risk issues. In terms of research methods, due to limited data collection, a suitable measurement model could not be established to carry out more in-depth research.

\section{Conflicts of Interest}

The author declares no conflicts of interest regarding the publication of this paper.

\section{References}

Becker, D., \& Rauscher, M. (2013). Fiscal Competition and Growth When Capital Is Imperfectly Mobile. The Scandinavian Journal of Economics, 115, 211-233. https://doi.org/10.1111/j.1467-9442.2012.01735.x

Di, J. (2016). Risk Analysis and Countermeasures of Local Government Debt in China. Nanning: Guangxi University.

Frankel, J. (2011). Over-Budget in Forecasts by Official Budget Agencies and Its Implications. Oxford Review of Economic Policy, 27, 536-562. https://doi.org/10.1093/oxrep/grr025

Gong, J. L. (2016). Risk Analysis of Local Government Debt under Implicit Guarantee of Central Government. Jinan: Shandong University.

Li, T. (2017). Research on Local Government Debt Risk in China. Times Finance, No. 29, $20+22$.

Wang, B., \& Yu, Y. M. (2015). Government Debt Scale and Local Financial Risk Prevention: A Case Study of Ningbo's Public Debt Crisis. Journal of Central University of Finance and Economics, No. 9, 17-22.

Wang, J. (2015). Risk Causes, Structure and Early Warning Evidence of Local Government Debt. China Economic Issues, No. 2, 13-25.

Wu, H. M., \& Feng, S. L. (2014). A Study of China's Local Government Debt with Regional and Provincial Characteristics. China Economic Journal, 7, 277-298. https://doi.org/10.1080/17538963.2014.961688

$\mathrm{Xu}$, P. C. (2016). Local Investment and Financing Platforms Contain Risks and Urgently Need Transformation. China Economic Times, 2016-12-29(005).

Zhang, W. W. (2018). Focusing on Audit Rectification: Why the Local Debt Problem Is Repeatedly Investigated and Repeatedly Violated? National People's Congress of China, No. 1, 34-36. https://doi.org/10.4236/jssm.2018.111004

Zhu, L. (2015). Research on Risk Management of Local Government Debt in China. Hangzhou: Zhejiang Gongshang University. 